\title{
The Roles and Responsibilities of Middle School Literacy Coaches across the US: National Study Results
}

\author{
Kristine M. Calo, PhD \\ Hood College \\ 401 Rosemont Avenue, Frederick, MD 21701, USA \\ Tel: 1-301-696-3572Ｅ-mail: calo@hood.edu
}

Received: October 30, 2011

Accepted: April 16, 2012

Published: May 1, 2012

doi:10.5296/jse.v2i2.1042

URL: http://dx.doi.org/10.5296/jse.v2i2.1042

\begin{abstract}
The present study explored the roles and responsibilities of middle school literacy coaches using surveys of randomly selected participants from across the United States followed by interviews of purposefully selected participants from different regions of the country. The interviews further explained the findings from the survey data analysis. The roles and responsibilities of the participants were found to be varied and multifaceted, influenced greatly by the context within which the coaches work, the administrators with whom they work, and the coaches' previous experiences. The study also explored the supports literacy coaches have in their schools/districts to help them be successful in their requisite roles. Identified supports included people, processes and resources. Given the vast range of roles and responsibilities of coaches across the country, the author calls for thinking about middle school literacy coaching as existing along a continuum from those who support only students on one end to those who work directly with teachers on the other end to help account for the fluidity of the role while also allowing for the influences of school/community contexts as well as the backgrounds and experiences of the coaches themselves. Presenting the role of the middle school literacy coach as a continuum rather than a one-size-fits-all role may allow for the range of literacy coaching roles/responsibilities while also providing for the flexibility that is needed as schools and districts identify their needs as an organization and determine how a literacy coach at the middle school level might help address these needs.
\end{abstract}

Keywords: literacy coaching, middle school, content area literacy, literacy 


\section{The Push for Secondary-level Literacy Coaches}

With the passage of the No Child Left Behind Act of 2001 a significant amount of funding and attention has been focused on kindergarten through third grade, with an aim at identifying and preventing the reading failure of young children. Many schools and districts across the United States have used literacy coaches or reading specialists to provide this early intervention.

Although there have been reading professionals at the secondary level for many years (Anders, 2002), there is increased interest in working directly with teachers to ensure that students are better able to access critical core information in content-area classrooms. Literacy coaches are in a unique position to provide this support. According to Shanklin (International Reading Association [IRA], 2007, I 3), literacy coaching is an ongoing "job-embedded form of professional development tailored to an individual teacher's need." The International Reading Association (2007) states that literacy coaching includes the following:

Collaborating with classroom teachers and paraprofessionals in a variety of ways, such as demonstrating lessons, assisting teachers in selecting best practices, designing programs that motivate all students, training classroom teachers to administer and interpret assessments, presenting professional workshops, conducting study groups, assisting classroom teachers in preparing curriculum materials (including technologically based information), assisting with assessment, and co-planning appropriate instruction. (Paradigm Shift Section, 2)

In today's world, literacy demands are daunting. It is more important than ever for adolescents to have the literacy skills and strategies they need to be successful in school and beyond. However, according to the 2009 National Assessment of Education Progress (NAEP) approximately $25 \%$ of our nation's eighth graders do not read at a "basic" level and many in the education field deem the results of the 2009 NAEP assessments in reading “disappointing” (Gewertz, 2010). The results, similar to those in the 2002 assessment, translates to one in four adolescents who is unable to do the following: identify the main ideas in passages read, understand expository passages, and/or extend the ideas they read in grade level texts (Kamil, 2003). Yet, the life-long value of high literacy skills is clear. In April 2007, the National Center for Education Statistics (NCES) released results from the 2003 National Assessment of Adult Literacy. The study found that "adults with higher literacy levels were more likely to be employed full-time and less likely to be out of the labor force than adults with lower literacy levels. Adults with lower literacy levels also generally earned lower incomes" (NCES, 2007, p. vi).

Although national tests do not necessarily show a decline in reading comprehension over the past 20 years, there does seem to be an increase in the expectations of reading over the years (Alvermann, 2002). In light of these increased demands, it is estimated that some eight million students in grades 4-8 are considered to be struggling readers (Alliance for Excellent Education [AEE], 2006). The statistics for U.S. adults are grim as well. The National Assessment of Adult Literacy (NCES, 2007) found that some 11 million adults in the United States are not literate in English and some 30 million have low literacy skills. And, equally as 
startling, the Journal of the American Medical Association (California Literacy, 2003) reports that some $46 \%$ of American adults are unable to even understand the labels on their prescription medicine bottles. The crisis is daunting but must be addressed to stem the tide of low literacy in the United States and ensure that our youth are equipped to take on the challenges of the $21^{\text {st }}$ century.

Despite the call for increasing the number of literacy coaches at the secondary level, presently little is known about what middle school literacy coaches actually do as well as why and how they do their jobs. Even less is known about how to support them in their endeavors. Education change specialist Michael Fullan noted that while there is a fair amount of literature written about the general topic of coaching, there is limited information available that depicts what literacy coaches actually do and ways in which they can become more effective in their roles (Burkins, 2007). A primary goal of this study was to give a voice to the literacy coaches across the country who work tirelessly to meet the needs of middle school students and teachers.

\section{Study Participants}

Participants in this study included 125 randomly-selected middle school coaches from across the country. Of the survey respondents, seven were purposefully selected to participate in open-ended interviews. Interviewees were selected based on their years of experience both as educators as well as in their roles as literacy coaches. Only coaches with 10 or more years of experience in education were selected as potential interview candidates. From this pool of candidates, participants were grouped into geographic regions based on the locations of their schools. The seven selected interviewees are from different geographic regions across the U.S., including West, Northwest, Midwest, South, Southeast, East, and Northeast. This criteria was purposefully established to ensure that no one state or region dominated the findings in this study in an attempt to capture a wider view of middle school literacy coaching in schools and districts all across the country.

\section{Data Collection}

Data from study participants were gathered from two primary sources-surveys and interviews - during the two phases of the study. After careful research, a survey instrument was found that had been used with elementary reading specialists in 2002 (Bean, Cassidy, Grumet, Shelton, \& Wallis, 2002) and then updated and implemented again with elementary reading specialists in 2004 (Pipes, 2004). Since this study focused on middle school literacy coaching and the survey was initially developed for use with elementary reading specialists, the survey instrument was adapted to meet the goals of the present research study. Adaptations to the instrument were made by consulting experts in the field and using research literature. As an additional check for validity for the adaptations, the survey instrument underwent a cognitive pretest (Fink, 2003a) with a middle school literacy coach to ensure that the questions as asked matched the coach's interpretations of the questions. After the early checks for validity and subsequent revisions, the survey instrument was pilot tested. The pilot test (Fink, 2003a; Litwin, 2003) was conducted with a group of middle school coaches from around the country, including Texas, Florida, Virginia, and California. Their feedback was 
collected and analyzed. Final changes were then made to the instrument based on this feedback. In the final administration of the survey, guidelines from survey literature were followed (Fink, 2003a; 2003b). This study yielded an overall response rate of $41 \%$ which was consistent with the response rate of the original survey administered by Bean and her colleagues (38\%).

\section{Data Analysis}

Data were analyzed using a mix of qualitative and quantitative methods. Descriptive statistics will be discussed in this article along with qualitative data from three open-ended survey questions and interviews. The qualitative analysis was conducted after the quantitative analysis to further explore the roles and responsibilities of middle school literacy coaches and to understand more fully how coaches work with content-area teachers.

\section{Multifaceted Roles and Responsibilities: Survey Findings}

To gain an understanding of the roles and responsibilities of middle school literacy coaches, participants were asked to identify how often they are involved in various activities including instructing students, assessment, co-planning, modeling, peer coaching, curriculum development, communicating with parents, guiding paraprofessionals, working with volunteers, and non reading-related tasks. Participants were also asked to identify the frequency of their involvement using a 1-5 scale, with 1 being not at all and 5 being daily. Table 1 depicts each activity followed by the percentage of respondents who reported each frequency, followed by the mean and the standard deviation. Survey respondents included literacy coaches from across the country. 
Table 1. Literacy Coaches’ Reported Involvement in Various Activities

\begin{tabular}{|c|c|c|c|c|c|c|c|}
\hline \multirow[b]{2}{*}{ Activity } & \multicolumn{5}{|c|}{ Frequency of Involvement } & \multirow[b]{2}{*}{ Mean } & \multirow[b]{2}{*}{ SD } \\
\hline & $\begin{array}{l}\text { Not at } \\
\text { all: }\end{array}$ & $\begin{array}{l}\text { Once a } \\
\text { month } \\
\text { or less: }\end{array}$ & $\begin{array}{l}\text { Several } \\
\text { times per } \\
\text { month: }\end{array}$ & $\begin{array}{l}\text { Several } \\
\text { times per } \\
\text { week: }\end{array}$ & Daily & & \\
\hline Instructing Students & $14 \%$ & $16 \%$ & $14 \%$ & $16 \%$ & $40 \%$ & 3.52 & 1.50 \\
\hline Assessment & $0 \%$ & $10 \%$ & $38 \%$ & $36 \%$ & $16 \%$ & 3.58 & 0.88 \\
\hline Co-planning & $4 \%$ & $10 \%$ & $34 \%$ & $42 \%$ & $10 \%$ & 3.44 & 0.95 \\
\hline Modeling & $8 \%$ & $26 \%$ & $40 \%$ & $20 \%$ & $6 \%$ & 2.90 & 1.02 \\
\hline Peer Coaching & $14 \%$ & $26 \%$ & $24 \%$ & $8 \%$ & $8 \%$ & 2.90 & 1.19 \\
\hline $\begin{array}{l}\text { Curriculum } \\
\text { Development }\end{array}$ & $6 \%$ & $14 \%$ & $38 \%$ & $30 \%$ & $12 \%$ & 3.28 & 1.05 \\
\hline $\begin{array}{l}\text { Parent } \\
\text { Communication }\end{array}$ & $12 \%$ & $40 \%$ & $28 \%$ & $14 \%$ & $6 \%$ & 2.62 & 1.07 \\
\hline $\begin{array}{l}\text { Guiding } \\
\text { Para-professionals }\end{array}$ & $40 \%$ & $34 \%$ & $14 \%$ & $10 \%$ & $2 \%$ & 2.00 & 1.07 \\
\hline $\begin{array}{l}\text { Working with } \\
\text { Volunteers }\end{array}$ & $56 \%$ & $30 \%$ & $10 \%$ & $4 \%$ & $10 \%$ & 1.62 & 0.83 \\
\hline $\begin{array}{l}\text { Non reading related } \\
\text { tasks }\end{array}$ & $36 \%$ & $34 \%$ & $20 \%$ & $4 \%$ & $6 \%$ & 2.10 & 1.13 \\
\hline
\end{tabular}

The majority of literacy coaches in this study indicated that they are involved with instructing students on a daily basis and are involved with co-planning several times per week. Many are either involved with assessment several times per month or several times per week (38\% and $36 \%$ respectively). The majority of participants indicated that they are involved with modeling instructional strategies several times per month. Participants were split in their reported involvement with peer coaching. Most participants reported being involved in curriculum development several times per month. The majority of participants in this study were involved with parent communication and guiding paraprofessionals fairly infrequently, while most indicated that they never are involved with volunteers. The majority of participants in this study said they are not regularly involved with non reading-related tasks. 
Working with content-area teachers. The majority of participants work with teachers in every content area (58\%), while another ten percent work with all content areas except for math. Eighteen percent of participants work only with reading/language arts. For the nearly 1 in 5 who only work with reading/language arts teachers, the adoption of the Common Core State Standards may influence this number and encourage schools to look more closely at cross-curricular support by literacy coaches to meet the rigorous literacy standards.

Table 2 summarizes some of the responsibilities that literacy coaches have when working with content-area teachers along with the percentages of literacy coaches in this study who perform these responsibilities. The majority of participants in this study provide teaching suggestions to content-area teachers, followed by providing materials.

Table 2. Working with Content-Area Teachers

\begin{tabular}{l|l}
\hline Responsibility & Yes (\%) \\
\hline Model & $70 \%$ \\
Co-plan & $64 \%$ \\
Co-teach & $46 \%$ \\
Provide materials & $80 \%$ \\
Provide teaching suggestions & $88 \%$
\end{tabular}

A Deeper Look at the Roles and Responsibilities of MS Literacy Coaches: Interview Findings

The interviews from this study provided a window into the range of experiences that literacy coaches at the middle school level have across the country. All seven of the interviewees had been in education for at least 11 years and had been a literacy coach for at least three years. Table 3 shows participant information. The contexts within which they worked were quite varied, including participants from rural, urban, and suburban settings.

Table 3. Interview Participants

Participant Pseudonym Years in Education $\quad$ Years as a Literacy Coach Region of U.S.

\begin{tabular}{llll}
\hline Kim & 20 & 2 & West \\
Anne & 16 & 7 & Northwest \\
Erin & 11 & 3 & Midwest \\
Julie & 20 & 3 & South \\
Pam & 15 & 9 & Southeast \\
Nicole & 16 & 5 & Northeast \\
Lisa & 30 & 19 & East
\end{tabular}

All of the participants were interviewed by phone for a minimum of 45 minutes to a maximum of 2.5 hours, with most lasting approximately an hour and a half. The interview participants identified numerous roles and responsibilities that they assume and discussed the challenges and benefits of their jobs. The general roles and responsibilities included working with or supporting teachers, working with or supporting students, and focusing on their own 
professional growth and development to stay abreast of current research in the field of literacy. Table 4 shows the specific roles and responsibilities they discussed.

Table 4. Roles and Responsibilities Discussed by Interviewees

\begin{tabular}{|c|c|}
\hline Most Used & Least Used \\
\hline $\begin{array}{l}\text { - } \text { working with data } \\
\text { - } \text { staying current with literacy research } \\
\text { - } \text { providing staff development } \\
\text { - } \text { collaborating with teachers } \\
\text { - } \text { providing resources } \\
\text { - } \text { modeling } \\
\text { - } \text { co-teaching } \\
\text { - } \text { co-planning } \\
\text { - } \quad \text { working with new teachers } \\
\text { - } \quad \text { conducting teacher observations } \\
\text { - } \text { providing feedback }\end{array}$ & $\begin{array}{ll}\text { - } & \text { working directly with students } \\
\text { - } & \text { incorporating technology } \\
\text { - } & \text { supporting classroom teachers } \\
& \text { observing other classroom teachers } \\
\text { - } & \text { developing curriculum } \\
\text { - } & \text { encouraging reflective practices } \\
\text { - } & \text { supporting alternative programs } \\
\text { - } & \text { serving on school committees } \\
\text { - } & \text { meeting with administrators } \\
\text { - } & \text { developing reading incentive programs }\end{array}$ \\
\hline
\end{tabular}

Modeling, co-teaching, and co-planning. Four of the interviewees discussed modeling, co-teaching, and co-planning as key responsibilities that they have as literacy coaches. These four coaches all primarily work with teachers in their roles. In the following excerpt, Pam, the coach from a small city in the Southeast with nine years of experience as a literacy coach and fifteen years in education, discussed how she purposefully sets aside time daily for modeling:

I set up maybe four appointments during the day to go in and model with teachers...and I like to stay after and see how the kids follow up on the lesson or talk to the teachers or even just get to know the kids...

Pam also discussed modeling while co-teaching so that teachers are an active part of the modeling process. She explained how she recently used this technique in a $7^{\text {th }}$ grade classroom:

We had a debate on the controversial issue of cell phones [in school]...It was like a jigsaw...We did it as a co-teaching lesson...There are lots of teachers who need modeling, but it helps them too where you're modeling, but they're in that modeling process with you. With some teachers I do a lot of that.

Pam and the others who shared that they work specifically with teachers to co-plan, model, and/or co-teach view their role as literacy coach as a job-embedded professional developer.

Supporting teachers observing teachers. Pam discussed how she provides support for teachers so that they can observe their colleagues. She conferences with teachers before and after observations, sets goals for the observation, provides note taking tools, and provides support after the observations as well, including planning for instruction or finding materials. This support role provides another avenue for job-embedded professional development and helps build collegiality in the school where all staff learn and share ideas. 
Observing teachers and providing feedback. The same four coaches also discussed observing teachers themselves and following up with feedback to identify areas in which they can further support these teachers. Julie, the coach from a small town in the South with 20 years of experience as an educator and three years as a literacy coach, shared that she also does "spot observations to get a sense of what's going on in the building." This helps her to gauge and engage in the culture of the building when it comes to literacy learning.

Working with data. All seven participants discussed assessment and working with data. For three of the coaches, their discussion of working with data focused on working with small groups of students. This was not surprising as their primary role as a literacy coach was working with students in their building. The assessments these coaches identified were informal assessments, online assessments, standardized assessments, and state assessments. All three-Anne, Erin, and Lisa—discussed using assessment data to drive their instruction with the struggling readers they service.

Julie and Pam discussed their role of collecting assessment data on students throughout the school as these two coaches took more of a teacher-focused stance in their role as literacy coaches. Julie focused on the quarterly interim assessments she administers, while Pam focused on the assessments that are mandated by her state for low-achieving students. Both emphasized helping teachers learn to use the data from assessments-both formal and informal-to drive their instructional choices.

Pam shared that she is responsible for all of the reading assessments in her school except for the state assessment. She noted that since her school does not have an assessment coordinator, she and a colleague are responsible for all of the progress monitoring of the lowest readers in the school as mandated by her state. She shared how overwhelming it can be with "just the two of us and hundreds of kids to assess." Along with coordinating the reading assessments in her school, Pam also works with teachers on using the student data to help achieve the school's and the teachers' goals.

Developing curriculum. Pam and Julie both also discussed working with teachers on lesson and unit development. Julie focused on the new social studies standards in her state and how "for some teachers it's a big struggle because they have their old textbooks and they don't know how to teach some of the new things.” Both also focused on incorporating strategy instruction across the content areas.

Working with new teachers. Four of the literacy coaches discussed working with new teachers. Erin, the literacy coach from the Midwest with three years of experience as a literacy coach, gives new teachers "quick things they can use to help their kids, like quick things with vocabulary." She explained that she focuses on "quick things" because "they're busy and I'm busy, so [I give them] something that I can teach them that they can use.” Erin went on to provide the following example: "if they say 'my kids are really struggling with something', I might say, 'Have you tried QAR [question-answer-relationships] with them yet? Let me help you."” 
Pam explained that her school has a considerable number of new teachers with varying degrees of experience, including career switchers. She noted that she assists these new teachers with administering their assessments. She models giving the assessments to " $1-2$ children to make sure that they [the teachers] understand how to administer the test...the best way for them to learn how to give it is to jump right in." Pam explained that to support the new teachers' learning, she will "sit with them while they're giving their first ones so that if they need help on the navigation piece it sometimes helps." She noted that the new teachers in her school welcome her openly, "they're like 'anytime, come in'... and they appreciate it."

Providing staff development. Six of the 7 interviewees spoke of providing some level of staff development for their school sites and/or districts. For example, Anne, the literacy coach from a rural region of the Northwest with 16 years of experience as a literacy coach, shared that at her school's quarterly staff development meetings she shares "presentations about easy things that teachers can use in their classrooms-comprehension strategies, strategies to go through the textbook to help students understand them." She noted that professional development at her school is difficult as teachers are reluctant to try new ideas so she limits her ideas to quick, easy ideas where teachers see the direct benefit to their own classrooms.

Julie discussed how she and her principal administered a needs assessment survey to their staff members. One way they used this data was to create an after-school inservice that was filmed and placed into their school's professional library. Julie shared that she is "involved in organizing professional development for our school and facilitating meaningful professional development for teachers.”

Nicole, the coach from a suburb of a large Northeastern city, focused on the power of the book studies that she facilitates for her school and district. She explained that books are selected based on district needs and staff interests: "We know that we need to write across the content areas...it's a combination of what we need, what people are interested in, and what's current.”

Encouraging reflective practice. Two of the interviewees focused on the importance of reflection. Kim, the coach from the West with twenty years of experience as a literacy coach, uses Cognitive Coaching (Costa \& Garmston, 1998) to help teachers reflect on their practices. She has found that this type of coaching is particularly effective because "people are really looking at what they're doing. I'm not telling them what to do. They're actually looking and thinking about what they're doing and how they feel about it.” Julie also said that she focuses heavily on helping teachers learn how to be reflective practitioners. One tool that she uses is videotaping teachers "just for themselves." She has found that using videotaping as a reflective tool is difficult because it is "hard to encourage people to get past "look how stupid I look on film' and to do that reflective work.”

Meeting with school administrators. Kim was the only coach who specifically mentioned planned meetings with a school administrator. Kim shared that the meetings focused on discussing the administrators' needs for assisting language arts teachers. While both Julie and Pam discussed meeting with their administrators, it was unclear whether these meetings were regularly scheduled meetings or impromptu meetings. 
Providing resources. Erin, Julie, Kim, and Pam all mentioned that one of their responsibilities included providing teachers with materials and resources. Erin noted that she houses the middle school book collection since the school does not have a school library. Julie talked about gathering books for book talks and helping teachers purchase books for their classroom libraries.

Pam shared that her school has a leveled bookroom with an online searchable database so that "each teacher has equal access to the bookroom." She explained that her role is to "weed through the materials, give them [teachers] catalogs and samples" and ensure that there are varied genres and forms including “...readers' theatre, descriptive, informational, instructional materials, magazines, plays, text sets...." Pam also shared that she provides teachers with resources for comprehension stations and classroom libraries.

Collaborating. Collaborating with classroom teachers was mentioned specifically by five interviewees. While Lisa, the coach from the East who works as a pull-out reading specialist, was not one of these five, she explained that although she does not collaborate with classroom teachers, she does collaborate with special education teachers.

Supporting after-school, Saturday school, and incentive programs. Lisa and Julie both discussed developing and supporting programs that take place outside of the regular school day. Lisa shared, "We do an after-school program on Mondays for students who are struggling with reading. We play games and have fun just to get them comfortable with language.” Julie discussed how she and others in her school have implemented a Saturday school program. Pam discussed how she worked to develop a reading incentive program based on time spent reading.

Serving on school committees. Only Pam discussed several committees that she serves on, including a Working on the Work Design Team and a Reading Leadership Team.

Working with students. All of the coaches interviewed in this study work with students, but in distinctly different ways. Anne, Lisa, and Erin each work primarily with students in small groups. Anne works with small groups of students who "scored novice" on the reading portion of their state assessment. Erin focuses on comprehension with struggling readers in grades 6-8. Instead of directly teaching students, Pam and Julie both spoke about connecting with middle school students. Since they do not pull groups, they look for connections in different ways than Lisa, Erin, and Anne including meeting with and supporting students informally.

Incorporating technology. The coaches in this study had varying degrees of competence and comfort with technology. Some, including Anne and Lisa, said they do not use it at all. Others, including Nicole and Julie, are beginning to see the power of technology. Nicole declared, "I'm going to start using it because...it's going to help me get into classrooms." She noted that teachers saw the power of technology as a way to engage students in literacy learning. Pam's school uses technology in many ways. Pam noted, "If there's a way to do something electronically, then we use it.” All teachers at her site have laptops. She shared that using technology when she co-teaches or models is an expectation at her school. 
Staying current. One of the responsibilities discussed by all interviewees was to stay current with literacy research. The coaches discussed different ways they do this including reading professional books and journals, taking classes, attending workshops, and attending meetings with other literacy coaches in their district or region. While some of the coaches received a considerable amount of professional development, others were frustrated by the lack of professional resources to which they have access and the desire to connect with other coaches in similar contexts.

\section{Supports for Successful Implementation of Roles and Responsibilities: Survey Findings}

The study also sought to explore the supports coaches have in their schools and/or districts to help them be successful in their requisite roles. Participants provided 106 responses. Through the data analysis it was found that the responses fell into three distinct categories: supportive people or organizations, supportive processes, and supportive resources.

Supportive people. Seventy-five percent of the responses focused on support provided by other people or organizations within and outside of their school districts. Support by a school administrator (principal or assistant principal) was mentioned by $18 \%$ of respondents. An equal percentage of respondents identified supportive district personnel as mentioned other literacy coaches within their districts (17\% respectively). Ten percent of respondents included teachers as a support. Three percent of the respondents included support provided by other non-literacy coaches including data coaches, math coaches, or graduation coaches. Supports outside the district included regional support centers, educational cooperatives, universities, and state reading organizations.

Supportive processes. Supportive processes put in place by schools or districts to support literacy coaches accounted for $13 \%$ of responses and included meetings, memos, and opportunities for planning. Meetings included monthly or quarterly meetings with other literacy coaches in the district or region, meetings with school administrators, or meetings with district-level supervisors.

Supportive resources. Resources such as training/professional development, technology, and funding were included in $12 \%$ of the responses. The most frequently mentioned resource was professional development for literacy coaches (10\%).

\section{Discussion}

The roles and responsibilities of middle school literacy coaches are numerous and diverse and ranged from those that involved working with and supporting students to those that involved working with and supporting teachers. Some of the roles identified in the present study include small-group interventionist, literacy assessment coordinator, curriculum developer, literacy intervention program coordinator, scheduler, co-planner, facilitator, collaborator, coach, mentor, materials purchaser and organizer, book room monitor, professional developer, committee leader, and community activist. These roles are similar to those found in previous research across the K-12 spectrum (e.g., Bean et al., 2007; Coggins, Stoddard, \& Cutler, 2003; Darwin, 2002; Smith, 2006). Along with having multifaceted roles and responsibilities, the participants in this study indicated that there are an array of supports that they have for 
successfully implementing their requisite roles and responsibilities. The present study found that there are a range of roles and responsibilities that middle school literacy coaches assume, and that the role looks different in different states, districts, and schools across the country. Furthermore, these roles and responsibilities are influenced by the communities and schools in which the coaches work and by the coaches' personal and professional experiences and backgrounds. There are some coaches whose primary role is to work in pull-out or push-in situations with small groups of struggling middle school readers. There are a number of coaches who work with small groups of students, but who also provide staff development for teachers. Some work only with English/language arts teachers while others provide job-embedded staff development to teachers in all content areas to help these teachers infuse literacy skills and strategies into their content-area instruction.

Given the vast range of roles and responsibilities of coaches across the country, thinking about middle school literacy coaching as existing along a continuum from those who support only students on one end to those who work directly with teachers on the other end may help account for the fluidity of the role as it is actually being implemented while also acknowledging the influences of school and community contexts as well as the backgrounds and experiences of the coaches themselves. Presenting the role of the literacy coach as a continuum rather than a one-size-fits-all role may allow for the range of literacy coaching roles/responsibilities while also providing for the flexibility that is needed as schools and districts identify what their needs are as an organization and determine how a literacy coach might help address these needs.

Take Anne and Erin from this study as examples. Both work primarily with students and provide minimal support to teachers. However, both of these coaches and their principals see a need for working more substantively with teachers and hope to make shifts in their roles for the upcoming school year to provide this support. Yet, they also see a need for continuing to work with groups of struggling readers because of the specific needs of their schools and communities-Erin's school has a considerable number of students from poverty and struggling readers entering $6^{\text {th }}$ grade annually and Anne's Native American community is faced with high levels of illiteracy. Like this study, Smith (2006) and Darwin (2002) found that the context of individual secondary schools played a significant role in what literacy coaches in their studies actually did on a daily basis. Because context can be such a powerful factor in what a coach does and how it is done, thinking along a continuum may provide schools a way to dialogue about what they want for their students, teachers, and paraprofessionals. Where literacy coaches would land on the continuum would depend on how coaches work with teachers, with which teachers they work, and in what capacity they work with students. A powerful discussion amongst all stakeholders could include (1) the experiences of the coach, (2) the literacy needs of the school both with respect to teachers and students, and (3) the needs of the community at large. The important work comes not from placing a coach along the continuum, but rather from the conversation that ensues from thinking and dialoguing about the roles and responsibilities a school community desires a literacy coach to assume based on needs. Poglinco and Bach (2004) warned that, "adopting a coaching model without considering its complexities may not yield the results schools and 
districts are seeking” (p. 398). Since stakeholder representation is an important part of ensuring the success of any initiative (Covey, 1999, 2001; Fullan, 2001, 2007), including school-based literacy professional development (NCTE, 2006), by including team/teacher leaders, administrators, coaches, and others in this dialogue, relationships and buy-in can be built as all stakeholders have a voice in determining the coach's roles and responsibilities and deciding how the coach will support the school's literacy initiatives and goals. Poglinco and Bach found that "with some advance planning and a more nuanced understanding of how coaching can work, administrators can make informed decisions about how to incorporate the use of coaches into their school improvement plans for optimum results” (p. 398).

\section{Final Thoughts}

Middle school is a pivotal time in the lives of adolescents. Literacy coaching is a significant investment on the part of the district, school, and teachers involved in the coaching process. As Michael Kamil (2003) stated, the time to make the investment in our children is now:

In today's knowledge-based society, our students need to be expert readers, writers, and thinkers to compete and succeed in the global economy. Furthermore, our high fourth-grade and low eleventh-grade international rankings for reading achievement show that an investment in the education of fourth- through twelfth-grade students is not just important-it is a national imperative. (p. 30)

The present study explores middle school literacy coaching across the continental United States and helps provide a glimpse into what literacy coaches actually do as well as how they perform their jobs. In conjunction with other studies on middle school literacy coaching (e.g., IRA, 2005; Poglinco et al., 2003; Smith, 2006) we are beginning to see the power of coaching at this level. More needs to be done to find out what impact these middle school literacy coaches are having on teachers' professional development as well as their impact on student achievement. The more information that researchers can provide about middle school literacy coaching in districts throughout the country, the more likely it may be for schools and districts to make the investment in and commitment to literacy coaching at the middle school level.

\section{References}

Alliance for Excellent Education. (2006). Who's counted? Who's counting: Understanding high school drop out rates. Washington, DC: Author.

Alvermann, D. E. (2002). Effective literacy instruction for adolescents. [Electronic version]. Journal of Literacy Research, 34(2), 189-208. From http://findarticles.com/p/articles/mi_qa3785/is_200207/ai_n9108028

Anders, P. L. (2002). Secondary reading programs: A story of what was. In D. L. Shallert, C. M. Fairbanks, J. Worthy, B. Maloch, \& J. V. Hoffman (Eds.), $51^{\text {st }}$ yearbook of the National Reading Conference (pp. 82-93). Oak Creek, WI: National Reading Conference.

Bean, R., Belcastro, B., Jenkins, K., Heisey, N., Zigmound, N., \& Wilson, R. (2007, November). What coaches do and why they do it: A diary study. Paper presented at the annual 
meeting of the National Reading Conference, Austin, TX.

Bean, R. M., Cassidy, J., Grumet, J. E., Shelton, D. S., \& Wallis, S. R. (2002). What do reading specialists do? Results from a national survey. The Reading Teacher, 55, 736-743.

Burkins, J. M. (2007) Coaching for balance: How to meet the challenges of literacy coaching. Newark, DE: IRA.

California Literacy. (2003). California health literacy information. Retrieved February 21, 2007, from http://cahealthliteracy.org/rc/2.html

Coggins, C.T., Stoddard, P., \& Cutler, E. (2003, April). Improving instructional capacity through school-based reform coaches. Paper presented at the meeting of the American Educational Research Association, Chicago, IL.

Covey, S. R. (1999). 4 roles of leadership. Salt Lake City, UT: Franklin-Covey Co.

Covey, S. R. (2001, May). 4 roles of leadership facilitator training manual. Salt Lake City, UT: FranklinCovey Co.

Creswell, J. W. (2005).Educational research: Planning, conducting, and evaluating quantitative and qualitative research. Upper Saddle River, NJ: Pearson.

Darwin, M. (2002). Delving into the role of the secondary reading specialist. Unpublished doctoral dissertation, George Mason University, Fairfax, Virginia.

Fink, A. (2003a). The survey handbook. Thousand Oaks, CA: Sage.

Fink, A. (2003b). How to conduct self-administered and mail surveys. Thousand Oaks, CA: Sage.

Fullan, M. (2007) The new meaning of educational change. San Francisco, CA: Jossey-Bass.

Fullan, M. (2001) Leading in a culture of change. San Francisco, CA: Jossey-Bass.

Gewertz, C. (July, 2010). NAEP reading results deemed disappointing. Education Week. Retrieved from http://www.edweek.org/ew/articles/2010/03/24/27naep.h29.html

International Reading Association. (2005). IRA surveys coaches.Newark, DE: Author. Retrieved from http://www.reading.org/publications/reading_today/samples/ RTY-0604-surveys.html

International Reading Association. (2006). Standards for middle and high school literacy coaches. Newark, DE: Author. Retrieved from http://www.reading.org/downloads/resources/597coaching_standards.pdf

International Reading Association. (2007). Literacy coaching: Still on the front burner. Newark, DE: Author. Retrieved from http://www.reading.org/publications/reading _today/samples/RTY-0702-coaching.html

Kamil, M. L. (2003). Adolescents and literacy: Reading for the $21^{\text {st }}$ century. Washington, DC: Alliance for Excellent Education. 


\section{Macrothink}

Journal of Studies in Education

ISSN 2162-6952

2012, Vol. 2, No. 2

Litwin, M. S. (2003). How to assess and interpret survey psychometrics. Thousand Oaks, CA: Sage.

Maxwell, J. (2005). Qualitative research design: An interactive approach (Rev. ed.). Thousand Oaks, CA: Sage.

National Center for Education Statistics. (2007). Literacy in everyday life: Results from

the 2003 national assessment of adult literacy. Retrieved from http://nces.ed.gov/Pubs2007/2007480.pdf

National Council of Teachers of English. (2006). NCTE principles of adolescent literacy reform: A policy research brief. Washington, DC: Author.

Pipes, G. (2004). What are they really doing?: A mixed-methods inquiry into the multifaceted role of the elementary reading specialist. Dissertation Abstracts International, 65, 04A, 1303.(UMI No. 2128178)

Poglinco, S. M., Bach, A. J., Hovde, K., Rosenblum, S., Saunders, M., \& Supovitz, J. A. (2003). The heart of the matter: The coaching model in America's choice schools. Philadelphia: University of Pennsylvania Consortium for Policy Research in Education.

Poglinco, S. M., \& Bach, A. J. (2004). The heart of the matter: Coaching as a vehicle for professional development. Phi Delta Kappan, 85, 398.

Smith, A. T. (2006). The middle school literacy coach: Roles, contexts, and connections to teaching. Retrieved from ProQuest Digital Dissertations database. (Publication No. AAT3224294) Appendix A: Tables and Figure 